\title{
Spindle cell lipoma of the mandibular mucogingival junction: a case report of unusual oral neoplasm
}

\author{
Manal Abdulaziz Al Sheddi ${ }^{1}$, Ahmad Assari $^{2}$ and Hezekiah Mosadomi ${ }^{2}$ \\ Spindle cell lipoma (SCL) is a benign lipomatous neoplasm typically located in the posterior neck and back of older males. It presents as \\ a well-circumscribed mass in the buccal mucosa, tongue, floor of the mouth or hard palate. There are only two case reports of SCL in the \\ gingiva and alveolar ridge. Here, we report a case of SCL in the mandibular mucogingival junction of a 68-year-old male. Clinical, \\ histopathological and immunohistochemical findings are presented. Although oral SCL is rare, it should be considered in the \\ differential diagnosis of spindle cell neoplasms occurring in the oral cavity. \\ International Journal of Oral Science (2014) 6, 185-187; doi:10.1038/ijos.2014.3; published 21 February 2014
}

Keywords: lipoma; mucogingival junction; oral cavity; spindle cell lipoma

\section{INTRODUCTION}

Lipoma is a common soft tissue tumor with several histopathological subtype, which occurs infrequently in the oral and maxillofacial region. ${ }^{1-2}$ One subtype is the spindle cell lipoma (SCL), which typically presents as a benign lipomatous neoplasm in the posterior neck and back of older males, and accounts for approximately $1.5 \%$ of all lipoma cases. ${ }^{3}$ In adult males, the most common location for classic oral and maxillofacial lipomas is the parotid region, followed by the buccal mucosa. ${ }^{4}$ However, oral SCLs are rare, and only about 40 cases have been reported. ${ }^{5}$ The histopathology of SCL is characterized by a mixture of mature adipose tissue, bland spindle cells and wiry collagen in focal myxoid stroma. ${ }^{3}$ The differential diagnosis of such an oral lesion would include classic lipoma, myolipoma, schwannoma, myxoid neurofibroma, leiomyoma, myxoid solitary fibrous tumor and atypical lipomatous tumors. ${ }^{6-7}$ Here, we report a case of SCL localized to the mandibular mucogingival junction in a 68 -year-old male, and the clinical, histopathological and immunohistochemical findings of this case are presented.

\section{CASE REPORT}

A 68-year-old male presented to the dental clinic of Riyadh Colleges of Dentistry and Pharmacy (Riyadh, Saudi Arabia) with a local region of swelling in his oral cavity that had persisted without pain over the past 3 years. Clinical examination revealed a $2 \mathrm{~cm} \times 1 \mathrm{~cm}$ sessile, soft tissue lump covered by intact oral mucosa (Figure 1 ). The medical and family histories for the patient were unremarkable.

An excisional biopsy was performed, and the patient did not exhibit evidence of recurrence during 12 months of follow-up.

The specimen resected was routinely processed and stained with hematoxylin and eosin, as well as with anti-CD34 (QB-END, 1:50;

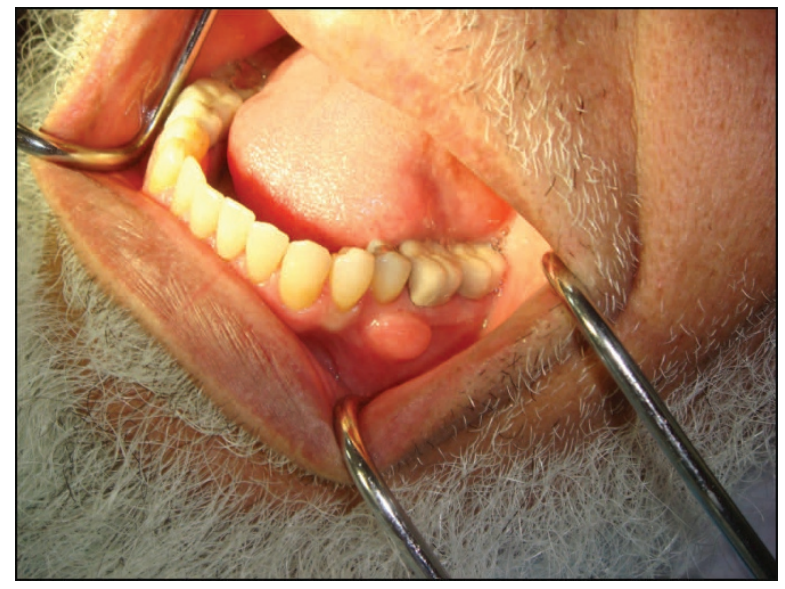

Figure 1 A dome-shaped nodule present at the left buccal mucogingival junction.

Novocastra, Newcastle, UK), anti-desmin (DER-11, 1:50; Novocastra, Newcastle, UK), anti-bcl-2 (bcl-2-486, 1:100; Novocastra, Newcastle, UK), anti-S-100 (S-100 P, 1:40) and anti-smooth muscle actin (SMA, $\alpha \mathrm{SM}-1,1: 50$; Novocastra, Newcastle, UK) antibodies. Hematoxylin and eosin staining revealed the proliferation of diffuse mature adipocytes among spindle cells in a lobular configuration. The tumor cells were bland with inconspicuous nuclei within a fibroblastic stroma that exhibited focal myxoid changes. No mitotic activity or necrosis was observed, and few mast cells were detected (Figure 2). Tumor cells were positive for expression of CD34 and bcl-2 in immunohistochemistry assays (Figure 3), while adipocytes, not spindle cells, were positive for S-100. No immunoreactivity to SMA or desmin was demonstrated.

${ }^{1}$ Department of Oral Medicine and Diagnostic Sciences, College of Dentistry, King Saud University, Riyadh, Saudi Arabia and ${ }^{2}$ Department of Oral and Maxillofacial Surgery and Diagnostic Sciences, Riyadh Colleges of Dentistry and Pharmacy, Riyadh, Saudi Arabia

Correspondence: Dr MA Al Sheddi, Department of Oral Medicine and Diagnostic Sciences, College of Dentistry, King Saud University, PO Box 230753, Riyadh 11321, Saudi Arabia E-mail: malshiddi@gmail.com

Accepted 18 December 2013 


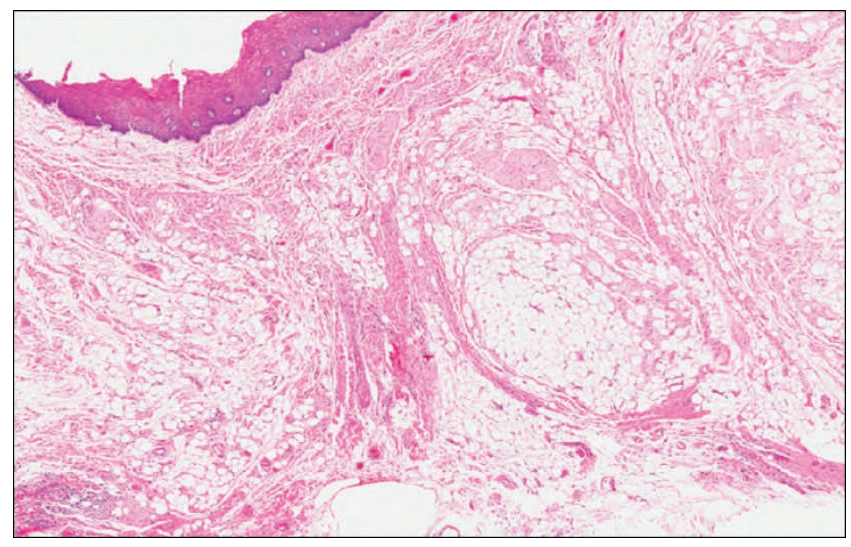

Figure 2 Mature adipocytes intermingled with spindle cells in a lobular configuration. Hematoxylin and eosin staining, magnification $\times 40$.
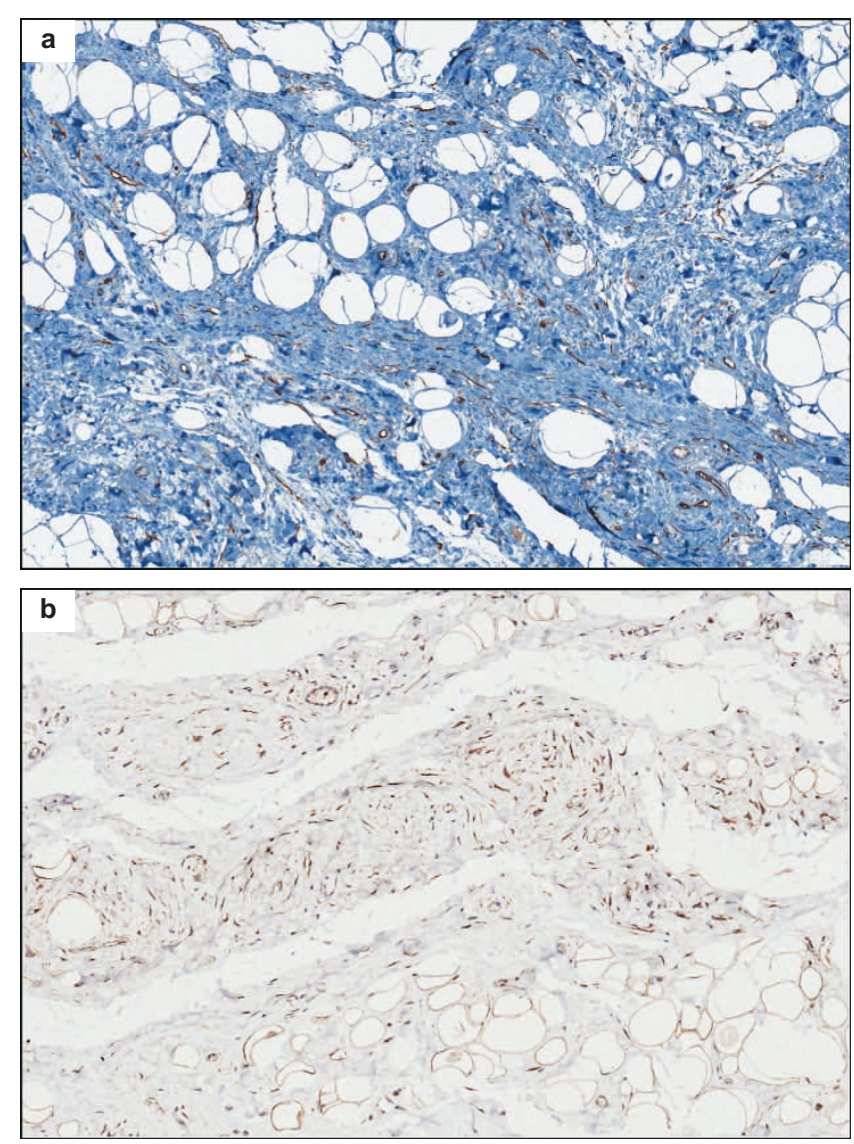

Figure 3 Tumor cells positive for expression of CD34 and bcl-2. (a) CD34; (b) bcl-2. Immunohistochemical staining, magnification $\times 40$.

\section{DIFFERENTIAL DIAGNOSIS}

SCL typically occurs as a solitary, painless and slow growing subcutaneous mass in the posterior neck or back of elderly males. Moreover, a slight predominance for SCL among males with an average age of 55 years has been observed. ${ }^{6}$ SCL has also been reported to affect other sites such as limbs, the parotid gland and hypopharynx. ${ }^{1}$ The tumor rarely exceeds $5 \mathrm{~cm}$ in diameter, and with adequate local excision, recurrence is uncommon. ${ }^{8}$ In contrast, localization of SCL to the oral cavity is extremely rare, and few case reports and small case series have been reported in the English literature. ${ }^{4,9-11}$ In these cases, SCL has presented as a wellcircumscribed mass that affects different anatomical locations within the oral cavity, including the buccal mucosa, tongue, floor of the mouth, hard palate and gingiva., ${ }^{5,1-12}$ Furthermore, there have been only two case reports of SCL in the gingiva and alveolar ridge mucosa. ${ }^{10-11}$

The histopathology of SCL is characterized by the presence of mature fat cells admixed with spindle cells arranged into prominent collagen bundles in a lobular pattern. Moreover, the proportion of spindle cells can vary. For example, some tumors are predominantly composed of mature adipocytes and a few scattered spindle cells, while others contain mostly spindle cells and only a small number of mature adipocytes. $^{3}$ In the current case, the spindle cell component represented a moderate proportion of the tumor. Regarding lesions in the oral cavity, a differential diagnosis can include: conventional lipoma, myolipoma, schwannoma, myxoid neurofibroma, leiomyoma, atypical lipomatous tumor and myxoid solitary fibrous tumors. ${ }^{6-7,12}$ Spindle cell and pleomorphic lipomas, which are now considered variants of the same lesion, are further characterized by losses on chromosomes $13 q$ and/or 16q. Expression of androgen receptors has also been documented for SCLs, suggesting a potential pathogenetic role for sex steroid hormones. ${ }^{13}$ However, for cases of oral SCL, this correlation has not been well studied. Furthermore, in one case report, no immunoreactivity to androgen, estrogen or progesterone receptors was demonstrated. ${ }^{14}$ Although these findings might suggest that a different pathogenetic pathway is associated with a SCL of the oral cavity, additional studies involving a larger number of cases are needed.

Previously, spindle cells have been found to express CD34 and bcl-2, yet not S-100. ${ }^{15}$ In the present case, tumor cells exhibited immunoreactivity for $\mathrm{CD} 34$ and bcl-2, and not for SMA and desmin. Moreover, spindle cells were negative for S-100, while mature adipocytes were strongly positive for. Immunoreactivity to desmin has been found to vary and therefore, should be analyzed with extreme care. In particular, the expression of desmin by lesions with non-classical histological features, or those occurring in atypical locations, should be closely considered. Furthermore, it has been reported that a significant proportion of SCLs express desmin. ${ }^{16}$ Overall, the clinical, histopathological and immunohistochemical profile of the present case supports a diagnosis of SCL. Therefore, complete surgical excision was performed, and the patient was monitored during a follow-up period, despite the low recurrence rates reported for SCL. ${ }^{6}$

\section{COMMENTS}

SCL is a benign neoplasm that should be considered for tumors identified in the oral cavity that include a spindle cell component. In addition, a correlation between histological and clinical features is essential for establishing a definitive diagnosis of SCL, in order to avoid a misdiagnosis.

\section{ACKNOWLEDGEMENTS}

The author is grateful for research support from the College of Dentistry Research Center, King Saud University, Riyadh, KSA, including laboratory technical assistance that was provided.

1 Rubin A. Weedon's skin pathology. 3rd ed. London: Churchill Livingstone Elsevier, 2010. 2 de Freitas MA, Freitas VS, de Lima AA et al. Intraoral lipomas: a study of 26 cases in a Brazilian population. Quintessence Int 2009; 40(1): 79-85.

3 Fletcher CD, Martin-Bates E. Spindle cell lipoma: a clinicopathological study with some original observations. Histopathology 1987; 11(8): 803-817.

4 Furlong MA, Fanburg-Smith JC, Childers EL. Lipoma of the oral and maxillofacial region: site and subclassification of 125 cases. Oral Surg Oral Med Oral Pathol Oral Radiol Endod 2004; 98(4): 441-450. 
5 Manor E. Spindle cell lipoma of the oral cavity: a clinico-pathologic analysis of 35 reported cases. Surg Sci 2013; 4(3): 196-201.

6 Kawasaki G, Yanamto S, Hirata K et al. Spindle cell lipoma of the cheek: a case report and review of literature. Oral Oncol Extra 2006; 42(10): 301-304.

7 Juliasse LE, Nonaka CF, Pinto LP et al. Lipomas of the oral cavity: clinical and histopathologic study of 41 cases in a Brazilian population. Eur Arch Otorhinolaryngol 2010; 267(3): 459-465.

8 Fletcher CD. Diagnostic histopathology of tumors. 2nd ed. Edinburgh: Churchil Livingstone, 2007.

9 Chandrashekhar $\mathrm{P}$, Jose M, Dadhich M et al. Spindle cell lipoma: a case report and review of literature. Kathmandu Univ Med J (KUMJ) 2012; 10(38): 92-95.

10 Agoff SN, Folpe AL, Grieco VS et al. Spindle cell lipoma of the oral cavity. Report of a rare intramuscular case with fine needle aspiration findings. Acta Cytol 2001; 45(1): 93-98.

11 Darling M, Thompson I, Schneider J. Spindle cell lipoma of the alveolar mucosa: a case report. Oral Surg Oral Med Oral Pathol Oral Radiol Endod 2002; 93(2): 171-173.

12 Tosios K, Papanicolaou SI, Kapranos N et al. Spindle cell lipoma of the oral cavity. Int J Oral Maxillofac Surg 1995; 24(5): 363-364.
13 Syed S, Martin AM, Haupt $\mathrm{H}$ et al. Frequent detection of androgen receptors in spindle cell lipomas: an explanation for this lesion's male predominance? Arch Pathol Lab Med 2008; 132(1): 81-83.

14 Vecchio G, Amico P, Caltabiano R et al. Spindle cell/pleomorphic lipoma of the oral cavity. J Craniofac Surg 2009; 20(6): 1992-1994.

15 Wood L, Fountaine TJ, Rosamilia L et al. Cutaneous CD34 ${ }^{+}$spindle cell neoplasms: histopathologic features distinguish spindle cell lipoma, solitary fibrous tumor, and dermatofibrosarcoma protuberans. Am J Dermatopathol 2010; 32(8): 764-768.

16 Tardío JC, Aramburu JA, Santonja C. Desmin expression in spindle cell lipomas: a potential diagnostic pitfall. Virchows Arch 2004; 445(4): 354-358.

(C) (i) (3) This work is licensed under a Creative Commons Attribution-

NonCommercial-ShareAlike 3.0 Unported License. The images or other third party material in this article are included in the article's Creative Commons license, unless indicated otherwise in the credit line; if the material is not included under the Creative Commons license, users will need to obtain permission from the license holder to reproduce the material. To view a copy of this license, visit http://creativecommons.org/licenses/by-nc-sa/3.0/ 